\title{
Crystallization of glass in fireclay refractories: part II: Detailed study on the mullite crystal content of the 'synthetic' glass
}

\author{
S P CHAUDHURI and T DATTA \\ Special Ceramics Section, Central Glass and Ceramic Research Institute, Calcutta 700032, India \\ MS received 31 July 1995; revised 2 November 1995

\begin{abstract}
A glass of composition similar to that found in fireclay refractories was synthesized and subsequently nucleated with $\mathrm{Cr}_{2} \mathrm{O}_{3}, \mathrm{~V}_{2} \mathrm{O}_{5}$ and $\mathrm{TiO}_{2}$. These glasses were heat-treated for crystallization of the mullite phase. The mulite content. the crystallization of mullite and the effect of temperature on the rate were investigated. The concentration of the nucleating oxides and the size and charge of their cations influence both the mullite content obtained and the crystallization rate.
\end{abstract}

Keywords. Fireclay; glass; mullite; nucleation; crystallization.

\section{Introduction}

Fireclay containing around $20 \mathrm{wt} . \% \mathrm{Al}_{2} \mathrm{O}_{3}$ is poor-grade and not suitable for making refractories. This is due to high concentration of low viscosity glass produced in the refractories. Improvement in the properties of the refractories is, however, possible by increasing the mullite crystal content.

It was shown (MacDowell and Beall 1969) that a glass composition of $\mathrm{Al}_{2} \mathrm{O}_{3}-\mathrm{SiO}_{2}$ system with $10-30 \mathrm{wt} . \% \mathrm{Al}_{2} \mathrm{O}_{3}$ is prone to crystallization by the nucleation growth process. As the $\mathrm{Al}_{2} \mathrm{O}_{3}$ content of the poor-grade fireclay products does not usually exceed $20 \mathrm{wt} . \%$, mullite crystals could be precipitated from fireclay glass by incorporating suitable oxides in it and then subjecting it to heat-treatment (Stookey 1959; Bergeron and Risbud 1984).

Earlier, McGee (1966) studied the constitution of fireclay. He concentrated on the mineralogical composition and strength of high-grade fireclay and kaolin clay. That the glassy phase in the fireclay products is a potential source of mullite has not been realized yet. This aspect is very important for poor-grade fireclay to develop high-grade refractory products from them. The present study, therefore, aims at understanding the crystallization of mullite from fireclay glass.

\subsection{Background}

Fireclay refractories of IS- 6 and IS- 8 qualities are manufactured from fireclays having $\mathrm{Al}_{2} \mathrm{O}_{3}$ content not less than $30 \mathrm{wt} \%$ and $40 \mathrm{wt} \%$, respectively. The reserve of such high-grade fireclays in the country is very low at present and the demand of fireclay refractories is met through import. In contrast to this situation, a huge quantity of low-grade $\left(\mathrm{Al}_{2} \mathrm{O}_{3}\right.$ content less than $20 \mathrm{wt} . \%$ and high flux content) fireclays is left unused or wasted. It is desired to improve the quality of such fireclays and to utilize these for making IS-6 and IS-8 type refractories. The motivation is to employ this otherwise waste material for appropriate useful application and also for import substitution. 
The upgrading of low-grade fireclays in terms of hot and cold mechanical strength, thermal-shock resistance and fusion point, may be possible by modification of the large pool of glassy phase in the low-grade fireclay products. The crystallization of the main phase, i.e. mullite, from the synthetic glassy phase resembling that in the products by incorporating nucleating agents and varying time and temperature schedule is, therefore, attempted. The concentration and size of mullite crystals as well as their rates of crystallization and change of size are investigated as the first step and the results are presented in the two papers.

Depending on the information generated from this study the raw low-grade fireclay will be investigated in the second step by mixing selected nucleating agent with it and employing suitable heating schedule for crystallization and growth of mullite phase in the fired products and also by determining their thermomechanical properties as mentioned before.

\section{Experimental}

\subsection{Analysis of fireclay}

The chemical composition of the fireclay was determined by wet chemical analysis. It was then fired at $1300^{\circ} \mathrm{C}$ for $1 \mathrm{~h}$ and crushed to fine powder. The crystalline phases were identified and estimated by X-ray analysis in a diffractometer (XRD).

The crystalline phases were mostly mullite and quartz. These were estimated by the internal standard technique in XRD (Klug and Alexander 1974). The $2.20 \AA$ and $1.52 \AA$ lines of mullite and $4 \cdot 26 \AA$ line of quartz were selected for this purpose.

\subsection{Composition of fireclay glass}

Mullite is composed of $\mathrm{Al}_{2} \mathrm{O}_{3}$ and $\mathrm{SiO}_{2}$ whereas quartz is only $\mathrm{SiO}_{2}$. Knowing the concentrations (wt. \%) of mullite and quartz and also the composition of fireclay, the amounts of $\mathrm{Al}_{2} \mathrm{O}_{3}$ and $\mathrm{SiO}_{2}$ in the crystalline phases were obtained. Therefore, the glass content (wt. \%) was determined to be 100-crystal content and its composition was calculated on the assumption that the remaining $\mathrm{Al}_{2} \mathrm{O}_{3}, \mathrm{SiO}_{2}$ and other oxides combined to yield glass.

\subsection{Synthetic glass preparation}

The glass was synthesized by melting a mixture of glass sand, alumina, $\mathrm{Na}_{2} \mathrm{CO}_{3}$, $\mathrm{K}_{2} \mathrm{C}_{2} \mathrm{O}_{4}, \mathrm{Fe}_{2} \mathrm{O}_{3}, \mathrm{TiO}_{2}, \mathrm{CaCO}_{3}$ and $\mathrm{MgCO}_{3}$ at $1300^{\circ} \mathrm{C}$. It was analysed by wet chemical method.

\subsection{Nucleation and crystallization of synthetic glass}

Glass powder was mixed with $\mathrm{Cr}_{2} \mathrm{O}_{3}(0 \cdot 5,1,1 \cdot 5 \mathrm{wt} \%), \mathrm{V}_{2} \mathrm{O}_{5}(1,3,5 \mathrm{wt} \%), \mathrm{TiO}_{2}(8,10$, $12 \mathrm{wt} \%), \mathrm{Cr}_{2} \mathrm{O}_{3}+\mathrm{V}_{2} \mathrm{O}_{5}(1+1,1 \cdot 5+3,0 \cdot 5+5 \mathrm{wt} \%)$ and $\mathrm{TiO}_{2}+\mathrm{V}_{2} \mathrm{O}_{5}(10+1,8+5$, $12+3 \mathrm{wt} \%$ ) thoroughly in stainless steel pot for $24 \mathrm{~h}$ and fired at $1300^{\circ} \mathrm{C}$ for $1 \mathrm{~h}$ in an electric furnace in platinum crucible. Each sample was cooled overnight after switching 
off the furnace, finely powdered and its crystallization temperature was determined from the DTA trace. It was around $1150 \mathrm{C}$.

Samples were heat-treated at $1110^{\circ}, 1130^{\circ}, 1150^{\circ}$ and $1170^{\circ} \mathrm{C}$ for $5,15,25$ and $35 \mathrm{~h}$ at each temperature and cooled overnight at the end of the run by shutting off the furnace. The temperature was raised at $5-7 \mathrm{C} / \mathrm{min}$.

\subsection{Estimation of mullite}

The X-ray calibration curves were drawn by plotting peak heights of $2.20 \AA$ and $1.52 \AA$ lines of mullite against concentration of mullite for four standard samples. The concentrations of mullite in the heat-treated glass samples were obtained by comparing the peak heights of these samples from the calibration curves.

\subsection{Mullite crystallization rate}

A nucleated glass sample was heat-treated at a fixed temperature for four different time periods. The mullite contents of these samples were plotted against time and the rate was calculated from the slope.

Table 1. Chemical composition (wt. \%)

\begin{tabular}{lccccccccc}
\hline & $\mathrm{SiO}_{2}$ & $\mathrm{Al}_{2} \mathrm{O}_{3}$ & $\mathrm{Fe}_{2} \mathrm{O}_{3}$ & $\mathrm{TiO}$ & $\mathrm{CaO}$ & $\mathrm{MgO}$ & $\mathrm{Na}_{2} \mathrm{O}$ & $\mathrm{K}_{2} \mathrm{O}$ & $\mathrm{LOI}$ \\
\hline Fireclay (raw) (CA) & 56.32 & 23.03 & 1.52 & 1.02 & 1.22 & 0.82 & 1.70 & 0.95 & 13.73 \\
Fireclay glass (Calc) & 69.40 & 20.20 & 2.20 & 1.50 & 1.80 & 1.20 & 2.50 & 1.40 & -- \\
Synthetic glass (CA) & 70.47 & 19.15 & 2.00 & 0.72 & 2.23 & 1.70 & 2.80 & 1.20 & $\cdots$ \\
\hline
\end{tabular}

CA, Chemical analysis: Calc., calculated.

Table 2. Concentration of mullite in samples containing $\mathrm{Cr}_{2} \mathrm{O}_{3}$.

\begin{tabular}{|c|c|c|c|c|c|}
\hline & Heating & Conc. of & nullite cry & tals 1 wt. $\%$ & at temp. \\
\hline & temp. $\rightarrow$ & $-\ldots-$ & $-\ldots$ & $-\cdots-$ & -- \\
\hline $\begin{array}{l}\text { Nucleating } \\
\text { agent }\end{array}$ & $\begin{array}{l}\text { Heating } \\
\text { time(h) }\end{array}$ & $1110 \mathrm{C}$ & $1130 \mathrm{C}$ & $1150 \mathrm{C}$ & $1170 \mathrm{C}$ \\
\hline $\mathrm{Cr}_{2} \mathrm{O}_{3}$ & $\downarrow$ & & & & \\
\hline-1 & $-{ }^{-}-$ & 0.25 & $-{ }^{-1.50}$ & 10.25 & 14.87 \\
\hline & 15 & $10 \cdot 12$ & $10 \cdot 56$ & $10 \cdot 37$ & $12 \cdot 12$ \\
\hline 0.5 wt. $\%$ & 25 & $10 \cdot 37$ & $10 \cdot 44$ & 10.87 & 11.06 \\
\hline & 35 & $10 \cdot 37$ & 11.57 & $11 \cdot 24$ & $10 \cdot 06$ \\
\hline & 5 & 8.00 & 8.62 & 8.75 & $12 \cdot 81$ \\
\hline & 15 & $8 \cdot 18$ & 9.06 & $9 \cdot 75$ & $10 \cdot 75$ \\
\hline $1.0 \mathrm{wt} \%$ & 25 & 11.00 & $10 \cdot 31$ & $10 \cdot 93$ & $10 \cdot 37$ \\
\hline & 35 & $10 \cdot 37$ & $11 \cdot 37$ & 11.00 & $8 \cdot 74$ \\
\hline & 5 & 7.93 & 8.69 & 9.06 & 10.87 \\
\hline & 15 & 8.75 & $10 \cdot 37$ & $10 \cdot 12$ & 9.93 \\
\hline $1.5 \mathrm{wt} \%$ & 25 & $7 \cdot 37$ & $9 \cdot 12$ & $10 \cdot 00$ & $8 \cdot 37$ \\
\hline & 35 & $9 \cdot 75$ & 9.25 & $9 \cdot 4.3$ & $10 \cdot 24$ \\
\hline
\end{tabular}


Table 3. Concentration of mullite in samples containing $\mathrm{V}_{2} \mathrm{O}_{5}$.

\begin{tabular}{|c|c|c|c|c|c|}
\hline \multirow[b]{2}{*}{$\begin{array}{l}\text { Nucleating } \\
\text { agent } \\
\mathrm{V}_{2} \mathrm{O}_{5}\end{array}$} & \multirow{2}{*}{$\begin{array}{c}\text { Heating } \\
\text { temp. } \rightarrow \\
\text { Heating } \\
\text { time(h) } \\
\downarrow\end{array}$} & \multicolumn{4}{|c|}{ Conc. of mullite crystals (wt. \%) at temp. } \\
\hline & & $1110^{\circ} \mathrm{C}$ & $1130^{\circ} \mathrm{C}$ & $1150^{\circ} \mathrm{C}$ & $1170^{\circ} \mathrm{C}$ \\
\hline \multirow{4}{*}{$1.0 \mathrm{wt} . \%$} & 5 & $11 \cdot 43$ & $12 \cdot 31$ & $12 \cdot 56$ & 12.62 \\
\hline & 15 & $10 \cdot 25$ & $12 \cdot 37$ & $11 \cdot 45$ & 12.06 \\
\hline & 25 & $12 \cdot 12$ & $12 \cdot 87$ & $10 \cdot 75$ & $11 \cdot 25$ \\
\hline & 35 & $12 \cdot 50$ & 13.87 & $12 \cdot 89$ & $10 \cdot 18$ \\
\hline \multirow{4}{*}{$3 \cdot 0 \mathrm{wt} . \%$} & 5 & $11 \cdot 24$ & $12 \cdot 12$ & $13 \cdot 94$ & $14 \cdot 87$ \\
\hline & 15 & $11 \cdot 75$ & $12 \cdot 62$ & $13 \cdot 62$ & $13 \cdot 50$ \\
\hline & 25 & $12 \cdot 75$ & $12 \cdot 40$ & $12 \cdot 87$ & $11 \cdot 25$ \\
\hline & 35 & $11 \cdot 62$ & $13 \cdot 12$ & $13 \cdot 25$ & 10.81 \\
\hline \multirow{4}{*}{5.0 wt. $\%$} & 5 & $12 \cdot 25$ & $12 \cdot 31$ & $11 \cdot 75$ & 12.89 \\
\hline & 15 & $10 \cdot 18$ & $12 \cdot 12$ & $10 \cdot 46$ & 12.43 \\
\hline & 25 & $12 \cdot 37$ & $12 \cdot 43$ & $11 \cdot 56$ & 10.87 \\
\hline & 35 & $11 \cdot 37$ & $12 \cdot 87$ & $12 \cdot 43$ & 10.56 \\
\hline
\end{tabular}

Table 4. Concentration of mullite in samples containing $\mathrm{TiO}_{2}$.

\begin{tabular}{|c|c|c|c|c|c|}
\hline \multirow[b]{2}{*}{$\begin{array}{l}\text { Nucleating } \\
\text { agent } \\
\mathrm{TiO}_{2}\end{array}$} & \multirow{2}{*}{$\begin{array}{c}\text { Heating } \\
\text { temp. } \rightarrow \\
\text { Heating } \\
\text { time(h) } \\
\end{array}$} & \multicolumn{4}{|c|}{ Conc. of mullite crystals (wt. $\%$ ) at temp } \\
\hline & & $1110^{\circ} \mathrm{C}$ & $1130^{\circ} \mathrm{C}$ & $1150^{\circ} \mathrm{C}$ & $1170^{\circ} \mathrm{C}$ \\
\hline \multirow{4}{*}{$8.0 \mathrm{wt} . \%$} & 5 & 6.62 & $7 \cdot 25$ & 8.62 & 12.50 \\
\hline & 15 & $8 \cdot 31$ & $11 \cdot 00$ & $9 \cdot 17$ & $9 \cdot 07$ \\
\hline & 25 & $7 \cdot 62$ & $8 \cdot 81$ & $9 \cdot 68$ & 9.94 \\
\hline & 35 & $9 \cdot 12$ & $9 \cdot 94$ & $9 \cdot 00$ & $8 \cdot 3 i$ \\
\hline \multirow{4}{*}{$10.0 \mathrm{wt} . \%$} & 5 & 6.75 & $7 \cdot 43$ & $7 \cdot 75$ & 6.93 \\
\hline & 15 & $5 \cdot 18$ & $7 \cdot 12$ & $7 \cdot 56$ & $6 \cdot 81$ \\
\hline & 25 & 8.00 & $8 \cdot 25$ & $7 \cdot 87$ & $6 \cdot 25$ \\
\hline & 35 & 7.50 & $8 \cdot 25$ & 8.00 & 7.00 \\
\hline \multirow{4}{*}{$12.0 \mathrm{wt} . \%$} & 5 & $4 \cdot 75$ & 6.68 & $6 \cdot 75$ & $5 \cdot 68$ \\
\hline & 15 & 4.87 & $7 \cdot 12$ & 6.94 & $6 \cdot 37$ \\
\hline & 25 & $6 \cdot 25$ & $7 \cdot 00$ & $6 \cdot 18$ & 6.50 \\
\hline & 35 & 5.75 & 6.37 & $6 \cdot 25$ & 6.43 \\
\hline
\end{tabular}

\section{Results}

The chemical analysis of the raw fireclay is shown in table 1. This suggests that the $\mathrm{Al}_{2} \mathrm{O}_{3}$ content of the glassy phase in the fireclay is still less.

The fired fireclay had $19 \mathrm{wt} \%$ mullite and $8 \mathrm{wt} \%$ quartz which accounted for $13.64 \mathrm{wt} \% \mathrm{Al}_{2} \mathrm{O}_{3}$ and $13.36 \mathrm{wt} . \% \mathrm{SiO}_{2}$ in the crystalline phase. The calculated chemical analysis of the fireclay glass is incorporated in table 1 . The chemical analysis of the synthetic glass is also given in this table.

The concentrations of mullite in the heat-treated synthetic glass samples are tabulated (tables 2-6). The crystallization rates of mullite in the samples are collected in 
Table 5. Concentration of mullite in samples containing $\left(\mathrm{Cr}_{2} \mathrm{O}_{3}+\mathrm{V}_{2} \mathrm{O}_{5}\right)$.

\begin{tabular}{|c|c|c|c|c|c|}
\hline \multirow[b]{2}{*}{$\begin{array}{l}\text { Nucleating } \\
\text { agent } \\
\left(\mathrm{Cr}_{2} \mathrm{O}_{3}+\mathrm{V}_{2} \mathrm{O}_{5}\right)\end{array}$} & \multirow{2}{*}{$\begin{array}{c}\text { Heating } \\
\text { temp. } \rightarrow \\
\text { Heating } \\
\text { time(h) } \\
\downarrow\end{array}$} & \multicolumn{4}{|c|}{ Conc. of mullite crystals (wt. $\%$ ) at temp } \\
\hline & & $1110 \mathrm{C}$ & $1130 \mathrm{C}$ & $1150 \mathrm{C}$ & $1170^{\circ} \mathrm{C}$ \\
\hline \multirow{4}{*}{$(1.0+1 \cdot 0) w t . \%$} & 5 & $9 \cdot 37$ & $10 \cdot 12$ & $9 \cdot 63$ & $10 \cdot 31$ \\
\hline & 15 & 8.75 & $10 \cdot 06$ & $10 \cdot 81$ & 11.74 \\
\hline & 25 & $10 \cdot 37$ & $10 \cdot 75$ & $10 \cdot 50$ & $9 \cdot 93$ \\
\hline & 35 & $10 \cdot 25$ & $11 \cdot 06$ & $9 \cdot 87$ & $10 \cdot 24$ \\
\hline \multirow{4}{*}{$(1.5+3.0)$ wt. $\%$} & 5 & $7 \cdot 87$ & $10 \cdot 18$ & $11 \cdot 12$ & $9 \cdot 22$ \\
\hline & 15 & 8.00 & $11 \cdot 00$ & $13 \cdot 50$ & $9 \cdot 93$ \\
\hline & 25 & $9 \cdot 50$ & $9 \cdot 37$ & $8 \cdot 75$ & $9 \cdot 81$ \\
\hline & 35 & $10 \cdot 12$ & $10 \cdot 00$ & $9 \cdot 75$ & 7.81 \\
\hline \multirow{4}{*}{$(0-5+5 \cdot 0)$ wt. $\%$} & 5 & $10 \cdot 87$ & 12.43 & $12 \cdot 37$ & $11 \cdot 41$ \\
\hline & 15 & $10 \cdot 00$ & $11 \cdot 75$ & $10-31$ & $11 \cdot 31$ \\
\hline & 25 & $11 \cdot 12$ & 11.62 & $10 \cdot 81$ & $11 \cdot 25$ \\
\hline & 35 & $10 \cdot 87$ & $11 \cdot 12$ & $11 \cdot 50$ & $11 \cdot 18$ \\
\hline
\end{tabular}

Table 6. Concentration of mullite in samples containing $\left(\mathrm{TiO}_{2}+\mathrm{V}_{2} \mathrm{O}_{3}\right)$.

\begin{tabular}{|c|c|c|c|c|c|}
\hline \multirow[b]{2}{*}{$\begin{array}{l}\text { Nucleating } \\
\text { agent } \\
\left(\mathrm{TiO}_{2}+\mathrm{V}_{2} \mathrm{O}_{5}\right)\end{array}$} & \multirow{2}{*}{$\begin{array}{c}\text { Heating } \\
\text { temp. } \rightarrow \\
\text { Heating } \\
\text { time(h) } \\
\downarrow\end{array}$} & \multicolumn{4}{|c|}{ Conc of mullite crystals (wt. $\%$ ) at temp. } \\
\hline & & $1110 \mathrm{C}$ & $1130 \mathrm{C}$ & $1150^{\circ} \mathrm{C}$ & $1170^{\circ} \mathrm{C}$ \\
\hline \multirow{4}{*}{$(10 \cdot 0+1 \cdot 0)$ wt. $\%$} & 5 & 6.00 & $6 \cdot 43$ & $6 \cdot 18$ & $6 \cdot 18$ \\
\hline & 15 & 7.06 & 7.57 & $7 \cdot 68$ & 6.75 \\
\hline & 25 & $6 \cdot 50$ & $7 \cdot 25$ & $6 \cdot 18$ & $7 \cdot 12$ \\
\hline & 35 & 6.00 & 6.75 & $6 \cdot 18$ & $6 \cdot 56$ \\
\hline \multirow{4}{*}{$(8 \cdot 0+5 \cdot 0) w t . \%$} & 5 & 6.87 & $8 \cdot 12$ & $7 \cdot 44$ & 6.93 \\
\hline & 15 & 6.24 & $8 \cdot 25$ & $7 \cdot 25$ & $7 \cdot 43$ \\
\hline & 25 & $7 \cdot 62$ & $7 \cdot 43$ & $7 \cdot 62$ & 6.93 \\
\hline & 35 & $7 \cdot 00$ & 7.93 & $7 \cdot 50$ & $7 \cdot 18$ \\
\hline \multirow{4}{*}{$(12 \cdot 0+3.0)$ wt. $\%$} & 5 & $5 \cdot 75$ & $5 \cdot 12$ & $5 \cdot 44$ & $5 \cdot 08$ \\
\hline & 15 & $5 \cdot 00$ & $7 \cdot 12$ & $6-58$ & $7 \cdot 06$ \\
\hline & 25 & $6 \cdot 12$ & 6.25 & 5.75 & 5.93 \\
\hline & 35 & $6 \cdot 38$ & $7 \cdot 18$ & $7 \cdot 12$ & 6.09 \\
\hline
\end{tabular}

table 7. The effect of concentration of nucleating agent, time and temperature of heattreatment on mullite content and the crystallization rate of mullite are revealed here.

The activation energies of mullite crystallization in the samples were estimated from the Arrhenius plots, $\log _{10} K^{\prime}$ vs $1 / T\left(K^{\prime}=\right.$ rate of mullite crystallization $)$ and recorded in table 8. A typical plot is illustrated in figure 1.

The dependence of concentration of mullite on the radius and charge of cations of $\mathrm{Cr}_{2} \mathrm{O}_{3}, \mathrm{~V}_{2} \mathrm{O}_{5}$ and $\mathrm{TiO}_{2}$ has been displayed in figures 2 and 3 , respectively. The radius and charge of $\mathrm{Cr}^{3+}, \mathrm{V}^{5^{+}}$and $\mathrm{Ti}^{4+}$ ions are plotted against the average mullite content 
Table 7. Rate of crystallization of mullite at different heat-treatment temperatures.

\begin{tabular}{|c|c|c|c|c|c|}
\hline \multirow{2}{*}{$\begin{array}{l}\text { Nucleating } \\
\text { agent } \\
\text { (N. A.) }\end{array}$} & \multirow{2}{*}{$\begin{array}{l}\text { Conc. of } \\
\text { (N. A.) } \\
(w t . \%)\end{array}$} & \multicolumn{4}{|c|}{$\begin{array}{c}\text { Crystallization rate }\left(K^{\prime}\right),\left[(w t . \% / \min .) \times 10^{3}\right] \\
\text { at temp. }\end{array}$} \\
\hline & & $1110^{\circ} \mathrm{C}$ & $1130^{\circ} \mathrm{C}$ & $1150^{\circ} \mathrm{C}$ & $1170^{\circ} \mathrm{C}$ \\
\hline \multirow[t]{4}{*}{$\mathrm{Cr}_{2} \mathrm{O}_{3}$} & $0 \cdot 5$ & 0.83 & $1 \cdot 33$ & $0 \cdot 66$ & $2 \cdot 50$ \\
\hline & $1 \cdot 0$ & $2 \cdot 33$ & 1.66 & $1 \cdot 30$ & $2 \cdot 30$ \\
\hline & $1 \cdot 5$ & 1.20 & $0-33$ & 1.60 & $0 \cdot 33$ \\
\hline & 1.0 & 0.55 & 0.55 & 0.83 & $1 \cdot 11$ \\
\hline \multirow[t]{3}{*}{$\mathrm{V}_{2} \mathrm{O}_{5}$} & $3 \cdot 0$ & $0 \cdot 33$ & 0.55 & 0.83 & $1 \cdot 66$ \\
\hline & 5.0 & $0 \cdot 48$ & 0.62 & 1.60 & $1 \cdot 33$ \\
\hline & 80 & $1 \cdot 40$ & $1 \cdot 42$ & 0.55 & $2 \cdot 25$ \\
\hline \multirow[t]{3}{*}{$\mathrm{TiO}_{2}$} & $10 \cdot 0$ & 0.67 & 0.48 & $0 \cdot 16$ & $0 \cdot 18$ \\
\hline & $12 \cdot 0$ & 0.55 & $0 \cdot 21$ & $0 \cdot 28$ & 1.66 \\
\hline & $(1 \cdot 0+1 \cdot 0)$ & $1 \cdot 11$ & $0 \cdot 55$ & 0.83 & 0.27 \\
\hline$\left(\mathrm{Cr}_{2} \mathrm{O}_{3}+\right.$ & $(1.5+3.0)$ & $1 \cdot 19$ & $0 \cdot 14$ & 1.90 & 0.66 \\
\hline \multirow[t]{2}{*}{$\left.\mathrm{V}_{2} \mathrm{O}_{5}\right)$} & $(0.5+5 \cdot 0)$ & $0 \cdot 17$ & $0 \cdot 71$ & 0.83 & 0.42 \\
\hline & $(100+1 \cdot 0)$ & 0.83 & 0.83 & 0.14 & 0.83 \\
\hline$\left(\mathrm{TiO}_{2}+\right.$ & $(8.0+5.0)$ & 0.55 & 0.15 & $0 \cdot 12$ & $0 \cdot 21$ \\
\hline $\left.\mathrm{V}_{2} \mathrm{O}_{5}\right)$ & $(12 \cdot 0+3 \cdot 0)$ & $0 \cdot 28$ & $1 \cdot 10$ & $1 \cdot 11$ & $0 \cdot 88$ \\
\hline
\end{tabular}

of the samples containing minimum, intermediate and maximum concentrations of the oxides to draw curves 1,2 and 3, respectively in these figures. Results are summarized in table 9.

\section{Discussion}

It appears from tables $2-6$ that, irrespective of experimental conditions, $\mathrm{V}_{2} \mathrm{O}_{5}$ is the most efficient mullite builder followed by $\mathrm{Cr}_{2} \mathrm{O}_{3}$ and $\mathrm{TiO}_{2}$. It is also noteworthy that heat-treatment at $1130^{\circ} \mathrm{C}$ for $\mathrm{V}_{2} \mathrm{O}_{5}$ containing samples, $1150^{\circ} \mathrm{C}$ for $\mathrm{TiO}_{2}$ containing samples and $1170^{\circ} \mathrm{C}$ for $\mathrm{Cr}_{2} \mathrm{O}_{3}$ containing samples seemed very suitable for crystallization of mullite. But higher temperature caused reduction in mullite content and better efficiency was observed at low concentration of the oxides.

It is also interesting to note that the addition of $\mathrm{V}_{2} \mathrm{O}_{5}$ to either $\mathrm{Cr}_{2} \mathrm{O}_{3}$ or $\mathrm{TiO}_{2}$ reduced the heat-treatment temperature from $1170^{\circ} \mathrm{C}$ in case of $\mathrm{Cr}_{2} \mathrm{O}_{3}$-containing samples and from $1150^{\circ} \mathrm{C}$ in case of $\mathrm{TiO}_{2}$-containing samples to $1130^{\circ} \mathrm{C}$ in each case without sacrificing the amount of mullite crystallization with only $\mathrm{Cr}_{2} \mathrm{O}_{3}$ or only $\mathrm{TiO}_{2}$. This has been the special advantage achieved by employing the mixed nucleants.

So far as their properties are concerned, $\mathrm{Cr}_{2} \mathrm{O}_{3}$ is a very refractory oxide and dissolves in glass to a very small amount. But $\mathrm{V}_{2} \mathrm{O}_{5}$ and $\mathrm{TiO}_{2}$ are both fluxing oxides and enter the glass in reasonable amounts (Morey 1938). The viscosity of the glass is, therefore, influenced by the amount of the oxides dissolved in it. While $\mathrm{V}_{2} \mathrm{O}_{5}$ and $\mathrm{TiO}_{2}$ reduced glass viscosity, $\mathrm{Cr}_{2} \mathrm{O}_{3}$ increased the same. Again $\mathrm{V}_{2} \mathrm{O}_{5}$ caused more reduction than $\mathrm{TiO}_{2}$. Depending on their melting points, the concentrations of these oxides in glass increased from $\mathrm{Cr}_{2} \mathrm{O}_{3}$ to $\mathrm{TiO}_{2}$. 


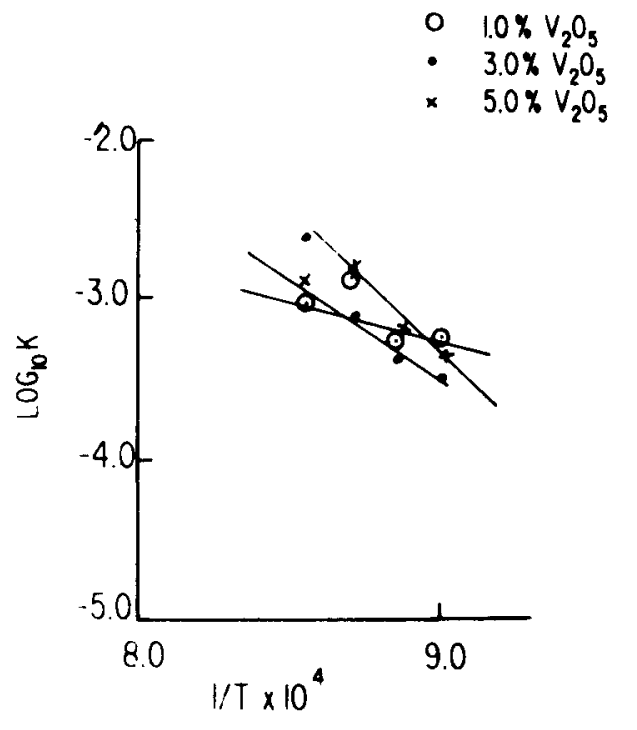

Figure 1. Arrhenius plot for rate of mullite crystallization $\left(K^{\prime}\right)$.

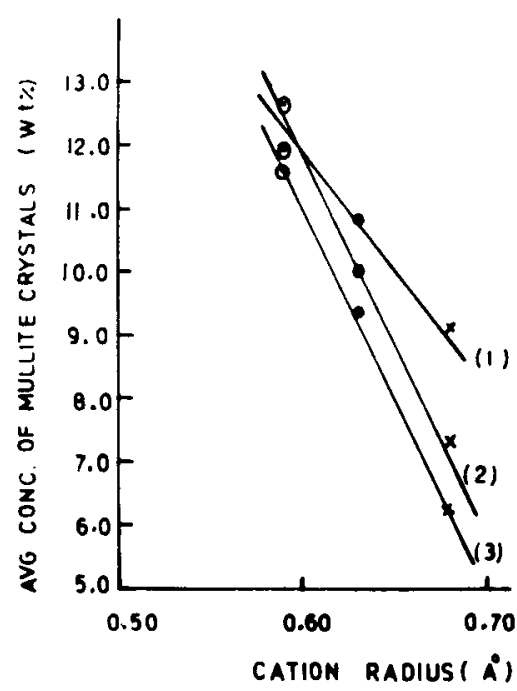

Figure 2. Dependence of average concentration of mullite on the cation radius of nucleating agent at (1) minimum, (2) intermediate and (3) maximum concentration of it.

These facts were mainly responsible for varying degrees of effectiveness of these oxides for crystallization of mullite from glass. So, $0.5 \mathrm{wt} . \% \mathrm{Cr}_{2} \mathrm{O}_{3}$ was found to be most efficient but only at $1170^{\circ} \mathrm{C}$. However, 1 wt. $\% \mathrm{~V}_{2} \mathrm{O}_{5}$ and $8 \mathrm{wt} \% \mathrm{TiO}_{2}$ showed best performance at $1130^{\circ} \mathrm{C}$. Similar reasons are applicable for the best results obtained from the use of $\left(\mathrm{Cr}_{2} \mathrm{O}_{3}+\mathrm{V}_{2} \mathrm{O}_{5}\right)$ and $\left(\mathrm{TiO}_{2}+\mathrm{V}_{2} \mathrm{O}_{5}\right)$ mixtures.

The nucleation and crystallization of glass needs generation of sufficient number of nuclei within it and lowering of free energy at glass-nucleus interface (Williamson 1970). 


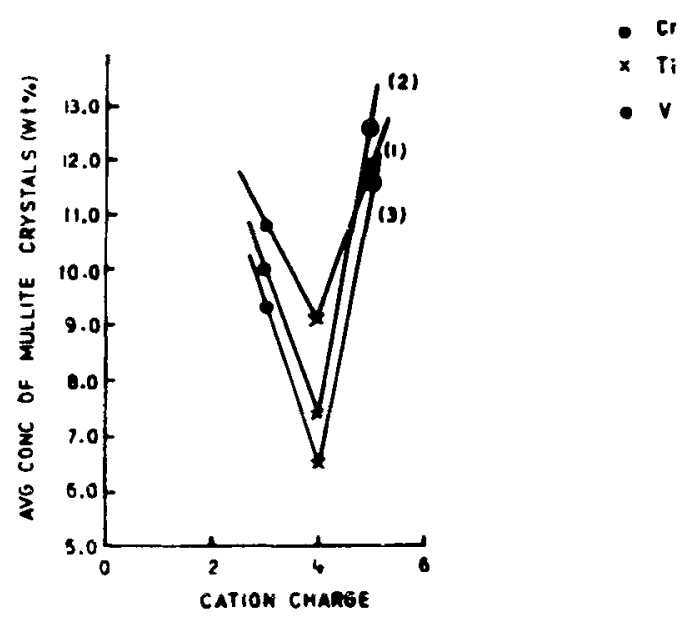

Figure 3. Dependence of average concentration of mullite on the cation charge of nucleating agent at (1) minimum, (2) intermediate and (3) maximum concentration of it.

Table 8. Activation energies of crystallization of mullite in the samples.

\begin{tabular}{|c|c|c|}
\hline $\begin{array}{l}\text { Nucleating agent } \\
\text { (N. A.) }\end{array}$ & $\begin{array}{c}\text { Conc. of N. A. } \\
\text { (wt. } \%)\end{array}$ & $\begin{array}{c}\text { Activation energy } \\
\text { (Kcillimol) }\end{array}$ \\
\hline \multirow[t]{4}{*}{$\mathrm{Cr}_{2} \mathrm{O}_{3}$} & 0.5 & $61 \cdot 1$ \\
\hline & 1.0 & $45 \cdot 8$ \\
\hline & $1 \cdot 5$ & $73 \cdot 2$ \\
\hline & 1.0 & $23 \cdot 0$ \\
\hline \multirow[t]{3}{*}{$\mathrm{V}_{2} \mathrm{O}_{5}$} & 3.0 & $51 \cdot 1$ \\
\hline & 5.0 & $81 \cdot 1$ \\
\hline & 8.0 & 458 \\
\hline \multirow[t]{3}{*}{$\mathrm{TiO}_{2}$} & 100 & 91.5 \\
\hline & 120 & $61 \cdot 1$ \\
\hline & $(1 \cdot 0+1 \cdot 0)$ & $61 \cdot 1$ \\
\hline \multirow[t]{3}{*}{$\left(\mathrm{Cr}_{2} \mathrm{O}_{3}+\mathrm{V}_{2} \mathrm{O}_{5}\right)$} & $(1 \cdot 5+3.0)$ & $73 \cdot 2$ \\
\hline & $(0.5+5 \cdot 0)$ & $61 \cdot 1$ \\
\hline & $(10-0+1.0)$ & $30 \cdot 5$ \\
\hline \multirow[t]{2}{*}{$\left(\mathrm{TiO}_{2}+\mathrm{V}_{2} \mathrm{O}_{5}\right)$} & $(8 \cdot 0+50)$ & $45 \cdot 6$ \\
\hline & $(12 \cdot 0+3 \cdot 0)$ & 460 \\
\hline
\end{tabular}

The crystallization of glass is enhanced by the increase in the nuclei number and decrease in the interfacial energy.

Among the three oxides, the radii (Moeller 1952; Day and Selbin 1962) of $\mathrm{Cr}^{3+}, \mathrm{V}^{5+}$ and $\mathrm{Ti}^{4+}$ ions are $0.63 \AA, 0.59 \AA$ and $0.68 \AA$, respectively. Therefore, maximum number of nuclei were available from $\mathrm{V}_{2} \mathrm{O}_{5}$, minimum from $\mathrm{TiO}_{2}$ and intermediate from $\mathrm{Cr}_{2} \mathrm{O}_{3}$. In unit volume of glass, $\mathrm{V}_{2} \mathrm{O}_{5}$ offered the highest number of sites for mullite crystallization which decreased from $\mathrm{Cr}_{2} \mathrm{O}_{3}$ to $\mathrm{TiO}_{2}$. The amount of mullite crystallized decreased from $\mathrm{V}_{2} \mathrm{O}_{5}$-containing samples to $\mathrm{TiO}_{2}$-containing samples (table 9).

The low activation energy of mullite crystallization of the $\mathrm{V}_{2} \mathrm{O}_{5}$-containing glass samples also suggests that $\mathrm{V}_{2} \mathrm{O}_{5}$ is superior to $\mathrm{Cr}_{2} \mathrm{O}_{3}$ and $\mathrm{TiO}_{2}$ as nucleating agent. 
Table 9. Efifect of radius and charge of cations of nucleating agents on average concentration of mullite.

\begin{tabular}{lcccc}
$\begin{array}{l}\text { Nucleating } \\
\text { agent } \\
\text { (N. A.) }\end{array}$ & $\begin{array}{c}\text { Cations } \\
\text { radius } \\
(\AA)\end{array}$ & $\begin{array}{c}\text { Cation } \\
\text { charge }\end{array}$ & $\begin{array}{c}\text { Conc. of } \\
\text { (N. A.) } \\
\text { wt. } \%\end{array}$ & $\begin{array}{c}\text { Avg. conc. } \\
\text { of mullite } \\
\text { wt. \% }\end{array}$ \\
\hdashline & & & 0.5 & 10.81 \\
$\mathrm{Cr}_{2} \mathrm{O}_{3}$ & 0.63 & 3 & 1.0 & 10.00 \\
& & & 1.5 & $9 \cdot 32$ \\
& & & 1.0 & 11.93 \\
$\mathrm{~V}_{2} \mathrm{O}_{5}$ & 0.59 & 5 & 3.0 & 12.58 \\
& & & 5.0 & 11.80 \\
& & & 8.0 & $9 \cdot 06$ \\
$\mathrm{TiO}_{2}$ & 0.68 & 4 & 10.0 & 7.29 \\
& & & 12.0 & 6.24
\end{tabular}

\section{Conclusions}

(1) The glassy phase in fireclay refractories can be partially crystallized to obtain mullite by nucleating the glass with $\mathrm{Cr}_{2} \mathrm{O}_{3}, \mathrm{~V}_{2} \mathrm{O}_{5}$ and $\mathrm{TiO}_{2}$ followed by heattreatment.

(2) The most efficient nucleating agent for crystallization of mullite from fireclay glass was $\mathrm{V}_{2} \mathrm{O}_{5}$ which was followed by $\mathrm{Cr}_{2} \mathrm{O}_{3}$ and $\mathrm{TiO}_{2}$. Addition of $\mathrm{V}_{2} \mathrm{O}_{5}$ to either $\mathrm{Cr}_{2} \mathrm{O}_{3}$ or $\mathrm{TiO}_{2}$ improved the efficiency of each.

\section{Acknowledgement}

One of the authors (TD) is grateful to CSIR, New Delhi for financial assistance to carry out this study.

\section{References}

Bergeron C G and Risbud S H 1984 Introduction to phase equilibria in ceramics (Columbus: American Ceramic Society) p. 38

Day M C and Selbin J 1962 Theoretical inorganic chemistry (New York: Reinhold Publishing Co.) p. 101

Klug H P and Alexander L E $1974 X$-ray diffraction procedures for polycrystalline and amorphous materials (New York: Wiley) 2nd ed.

MacDowell J F and Beali G H $1969 \mathrm{~J}$. Am. Ceram. Soc. 5217

McGee T D 1966 J. Am. Ceram. Soc. 4983

Moeller T 1952 Inorganic chemistry-an advanced text book (New York: Wiley) p. 127

Morey G W 1938 The properties of glass (New York: Reinhold Publishing Co.) p. 135

Stookey S D 1959 Indust. Engg. Chem. 51805

Williamson J 1970 Miner. Mag. 37758 